\title{
$P P B P$ and DEFA1/DEFA3 genes in hyperlipidaemia as feasible synergistic inflammatory biomarkers for coronary heart disease
}

Yaowapa Maneerat ${ }^{1 *}$, Kriengchai Prasongsukarn$^{2}$, Surachet Benjathummarak ${ }^{3}$ and Wilanee Dechkhajorn ${ }^{1}$

\begin{abstract}
Background: Coronary heart disease (CHD) is an important complication of atherosclerosis. Biomarkers, which associate with CHD development, are potential to predict CHD risk. To determine whether genes showing altered expression in hyperlipidaemia $(\mathrm{H})$ and coronary heart disease (CHD) patients compared with controls could be CHD risk biomarkers.

Methods: Control, $\mathrm{H}$, and CHD groups represented atherosclerosis to CHD development. Gene profiling was investigated in peripheral blood mononuclear cells using DNA microarrays. Eight selected genes expressed only in $\mathrm{H}$ and CHD groups were validated by real-time quantitative reverse transcription PCR and plasma protein determination.

Results: a-defensin (DEFA1/DEFA3), pro-platelet basic protein (PPBP), and beta and alpha2 hemoglobin mRNA expression was significantly increased in $\mathrm{H}$ and CHD groups compared with controls, but only plasma PPBP and a-defensin proteins were correspondingly increased.
\end{abstract}

Conclusion: PPBP and DEFA1/DEFA3 could be potential CHD biomarkers in Thai hyperlipidaemia patients.

Keywords: Hyperlipidaemia, Coronary heart disease, Inflammation, Biomarker, PPBP, a-defensin

\section{Background}

Atherosclerosis is a complicated, progressive disease characterized by the accumulation of lipids and fibrous elements in large and medium-sized arteries. It is the major underlying cause of cardiovascular disease (CVD), which in turn is the leading cause of death in the developed world, and an important cause of morbidity worldwide. Abundant previous studies have linked dyslipidaemia to atherogenesis, and roles have been identified for inflammatory mechanisms coupled with dyslipidaemia in atheroma formation both in humans and animal models [1-3]. Early atherogenesis is characterized by leukocyte recruitment and the expression of pro-inflammatory cytokines, as shown by the fact that defective inflammatory mediators reduce atheroma formation in mice [2]. Inflammatory

\footnotetext{
* Correspondence: yaowapa.man@mahidol.ac.th

${ }^{1}$ Department of Tropical Pathology, Faculty of Tropical Medicine, Mahidol University, Bangkok 10400, Thailand

Full list of author information is available at the end of the article
}

pathways also promote the development of thrombosis, which is a serious, late complication of atherosclerosis responsible for myocardial infarctions and coronary heart disease (CHD), associated with an increased risk of sudden death [3].

Atherogenesis and CHD involve a long preclinical process. Multiple risk factors have been identified for CHD without familial hypercholesterolaemia including behavioral, dietary, and lifestyle factors such as smoking, dietary fat intake, level of physical activity, infections (exogenous exposure), alteration of endogenous blood constituents such as lipid and lipoprotein particles, inflammation and coagulation proteins, intermediary metabolites, and oxidant markers of stress, adiposity, blood pressure, and diabetes mellitus [4]. Several clinical evaluations are available for patients with CVD and CHD, including diagnostic tests of varied accuracy, reproducibility, ease of use, and potential for patient morbidity [5]. 
Blood is an accessible source for diagnosing various disease processes [6], and is also an appropriate representative for atherosclerotic tissue because it contains inflammatory cells, which play an important role in atherogenesis [7]. Currently, few simple blood-based biomarkers are available for the well-defined validation of $\mathrm{CHD}$ patients [8]. Biomarkers such as C-reactive protein have been associated with future cardiovascular event risk $[9,10]$, while recent studies have revealed the potential of identifying differential gene expression in peripheral blood samples from CVD patients [11, 12]. Previous studies used the expression profiling of peripheral blood mononuclear cells (PBMCs) to study the pathogenesis, diagnosis, and pharmacokinetics of human atherosclerosis, stroke, and other vascular diseases [6, 13-15]. The present study took a similar approach to investigate gene expression differences associated with atherosclerosis and CHD complications using PBMCs from healthy controls $(\mathrm{N})$, and non-familial hyperlipidaemia $(\mathrm{H})$ and CHD patients. Here, we aimed to 1) investigate the intersection of gene profiling expression in $\mathrm{H}$ and $\mathrm{CHD}$ patients but not $\mathrm{N}$ individuals; and 2) verify whether the selected (intersected) genes could be biomarkers of CHD risk in Thai hyperlipidemia patients. Our study provides preliminary information for further in-depth studies to define appropriate biomarkers in hyperlipidaemia populations for the surveillance and prediction of long-term CHD development. In the present study, we hypothesized that our biomarkers may have valuable clinical applications. The decreased or undetectable expression of these markers in treated hyperlipidaemia patients could be used as an indicator for the effective prevention of atherogenesis and its development into CHD.

\section{Methods \\ Materials}

Dulbecco's phosphate-buffered saline (D-PBS) and TRIzol reagent were purchased from Invitrogen (Carlsbad, CA, USA), the IsoPrep RNeasy total RNA kit was from Qiagen (Hilden, Germany), and the Affymetrix GeneChip Human Gene 1.0 ST Array was from Affymetrix (Santa Clara, CA, USA). Quantitative reverse transcription (qRT)-PCR primers were designed using Primer3 (v.0.4.0) software, GenBank sequences and based on previous studies, and were synthesized by Pacific Science Co., Ltd. (Bangkok, Thailand). The specificity of the primers for the target genes was also determined using the BLAST program [16]. Human HNP 1-3 enzymelinked immunosorbent assay (ELISA) reagents were purchased from Hycult Biotech (Uden, the Netherlands). All other reagents were from Sigma-Aldrich (St. Louis, MO, USA).

\section{Study design and patient population}

The patient flow and experimental design are summarized in Fig. 1. The study was conducted in the Department of Tropical Medicine, Mahidol University. Approval for the study was obtained from the Ethics Committees of the Faculty of Tropical Medicine, Mahidol University (MUTM2012-031-01), and Pramongkutklao Hospital (Q004q/55_Exp). Before enrollment, all participants were informed of the study objectives, and completed an informed consent form.

\section{Patients}

All volunteers were unrelated males born to Thai parents. Twenty healthy controls were recruited who carried no infections, and had no underlying disease or $\mathrm{CVD}$ risk factors ( $\mathrm{N}$ group). Forty-five patients were diagnosed, classified, and treated by a specialist (KP) at Pramongkutklao Hospital. They were classified into two groups based on their clinical manifestations according to the American College of Cardiology/American Heart Association criteria (2013) [17], including $24 \mathrm{H}$ patients with high cholesterol levels [total cholesterol (TC), lowdensity lipoprotein (LDL), and high-density lipoprotein (HDL)], but with no evidence of vital organ dysfunction, and 21 patients diagnosed with CHD who were about to undergo coronary bypass grafting under the supervision of KP. No patients or controls had received any cholesterol or blood pressure-lowering medication.

\section{Blood sample collection and methods}

Heparinized blood samples $(5 \mathrm{ml})$ were collected once from healthy controls and from all patients before hyperlipidaemia treatment or coronary bypass grafting. Plasma $(2 \mathrm{ml})$ was immediately collected by centrifugation of whole blood. Plasma aliquots were prepared for lipid measurement, and kept at $-70{ }^{\circ} \mathrm{C}$ for the detection of plasma proteins encoded by the selected genes.

Packed blood cells were resuspended in D-PBS (Wisent Inc., Quebec, Canada) and used to isolate mononuclear cells. Approximately $2 \times 10^{6}$ PBMCs in TRIzol (Invitrogen) were kept at $-70{ }^{\circ} \mathrm{C}$ for gene expression profiling by DNA microarray analysis using Affymetrix GeneChip Human Gene 1.0 ST (Affymetrix).

\section{Lipid test}

Lipid markers including TC, triglycerides (TG), LDL cholesterol (LDL-c), and HDL cholesterol (HDL-c) were analyzed enzymatically using kits (Randox Laboratories limited, Crumlin, UK) and a biochemistry analyzer (Architect CI 16200, Abbott Laboratories, Abbott Park, IL, USA). 


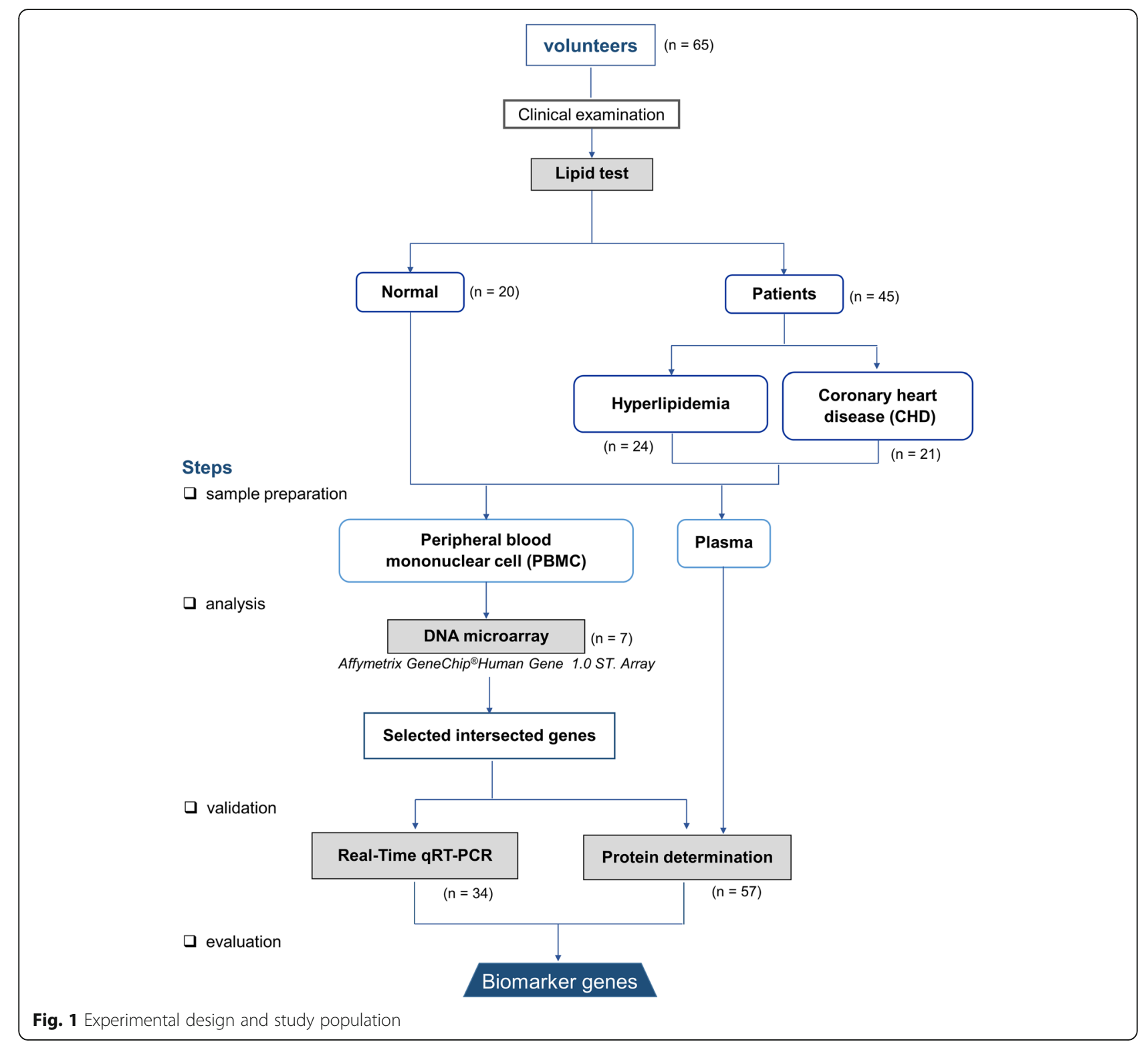

Peripheral blood mononuclear cell separation and gene expression profiling using DNA microarray analysis PBMCs were separated by Isoprep gradient centrifugation according to the manufacturer's recommendations (Robbins Scientific Corporation, Sunnyvale, CA, USA).

Total RNA was extracted from $2 \times 10^{6}$ PBMCs of all patients and controls $(n=7)$ using RNA isolation kits (Qiagen). Total RNA was measured using a NanoDrop ND-1000 spectrophotometer with ND-1000 3.3 software, and RNA integrity (RIN) was determined using an Agilent Bioanalyzer (Santa Clara, CA, USA). The Affymetrix GeneChip Human Gene 1.0 ST array was performed using $5 \mu \mathrm{g}$ of total RNA with $\mathrm{RIN} \geq 8.0$, according to the manufacturer's protocol (Affymetrix Inc). The data were analyzed by Agilent GeneSpring GX Software version 12.0. Differentially expressed genes correlating with inflammation were identified using the criteria of a > 2.0-fold increase/decrease in expression in $\mathrm{H}$ and CHD patients compared with the $\mathrm{N}$ group [18]. Figure 2 shows heat maps of differentially expressed transcripts in PBMCs from $\mathrm{H}$ patients vs. controls, and CHD patients post-coronary bypass grafting vs. controls. These were then further evaluated to determine their feasibility as inflammatory biomarkers of CHD development [19].

\section{Quantitative reverse transcription PCR analysis of the} mRNA expression of selected genes

Eight intersected genes, showing increased expression in $\mathrm{H}$ and $\mathrm{CHD}$ patients, were selected for further validation. These were: $\alpha$-defensin (DEFA1/DEFA3), proplatelet basic protein $(P P B P)$, beta haemoglobin $(H B B)$, alpha 2 haemoglobin (HBA2), superoxide dismutase 2, 

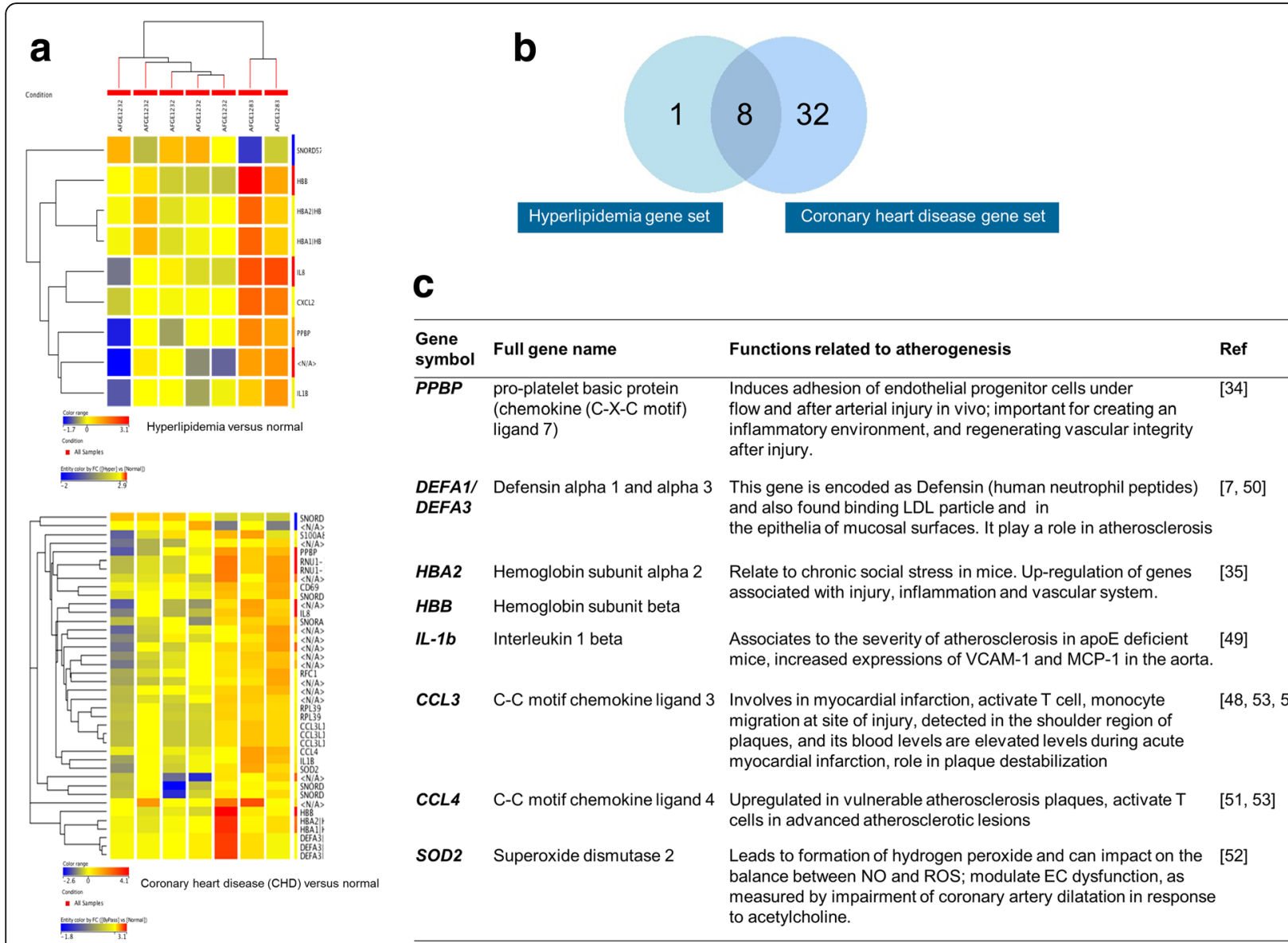

Fig. 2 Gene expression profiling by DNA microarray. Total RNA was extracted from $2 \times 10^{6}$ peripheral blood mononuclear cells (PBMCs) $(n=7)$. Differentially expressed genes $>$ 2.0-fold change were further evaluated. (a) Heat maps of differentially expressed transcripts in PBMCs from hyperlipidaemia patients vs. control, and coronary heart disease (CHD) patients post-coronary bypass grafting vs. control. (b) Venn diagram illustrating the eight genes up-regulated in the two patient groups. (c) List of the eight genes common to both patient groups and their functions $[7,34,35,48-54]$

(SOD2), chemokine ligand 3(CCL3), and 4 (CCL4), and interleukin-1 $\beta(I L-1 \beta)$. Table 1 lists the primers designed to amplify these genes and their expected fragment lengths. qRT-PCR was performed in duplicate [20]. Each $20-\mu \mathrm{l}$ PCR reaction contained $10 \mu \mathrm{l}$ of LightCycler 480 SYBR Green I Master mix (Roche Diagnostic, Mannheim, Germany) mixed with $100 \mathrm{ng}$ of cDNA and $0.5 \mu \mathrm{M}$ of each set of forward and reverse primers (Table 1). Amplification was conducted in a Bio-Rad CFX96 Real-time system (BioRad Laboratories, Inc., Hercules, CA, USA). PCR conditions were $95{ }^{\circ} \mathrm{C}$ for $5 \mathrm{~min}$, followed by 45 cycles of denaturation at $95{ }^{\circ} \mathrm{C}$ for $30 \mathrm{~s}$, annealing at $60{ }^{\circ} \mathrm{C}$ for $30 \mathrm{~s}$, and melting curve analysis at $65{ }^{\circ} \mathrm{C}$ for $1 \mathrm{~min}$ [13]. ACTB primers (forward: $5^{\prime}-$ TCACCCACACTGTGCCCATCTACGA-3' and reverse: 5' -CAGCGGAACCGCTCATTGCCAATGG-3') were used to normalize the relative expression level of each gene $[21,22] .2^{-(\Delta \Delta C t)}$ was used to calculate the relative expression level.

\section{Determination of plasma IL-1 $\beta$, PPBP, CCL3, and CCL4 protein levels}

Plasma levels of IL-1 $\beta$, CCL3, CCL4, and PPBP were assayed using the MILLIPLEX MAP human cytokine/ chemokine magnetic bead Panel III kit (Millipore Corporation, Billerica, MA, USA) according to the manufacturer's instructions and based on a previous study [23]. Briefly, after soaking wells with $200 \mu \mathrm{l}$ of assay buffer, $25 \mu \mathrm{l}$ standard or assay buffer, $25 \mu \mathrm{l}$ matrix solution or plasma (1:100), and $25 \mu \mathrm{l}$ beads was added to the wells and incubated overnight at $4{ }^{\circ} \mathrm{C}$ with shaking. After vacuuming and washing twice with wash solution, $25 \mu \mathrm{l}$ of detection antibodies was added and incubated for $2 \mathrm{~h}$ at room temperature. Then, $25 \mu \mathrm{l}$ of streptavidin-phycoerythrin was pipetted and incubated for $30 \mathrm{~min}$ before vacuuming and washing, followed by the addition of $100 \mu \mathrm{l}$ sheath fluid to each well. Measurements were performed using Luminex MAGPIX (BioRad) and interpreted by xPONENT ${ }^{\circ}$ software (Merck Millipore). 
Table 1 Primers for gene amplification in Real-Time qRT-PCR

\begin{tabular}{|c|c|c|c|c|c|}
\hline Gene & Accession no. & Primer sequence $\left(5^{\prime}-3^{\prime}\right)$ & $\begin{array}{l}\text { Length } \\
\text { (bp) }\end{array}$ & Length (bp) & REF \\
\hline \multirow[t]{2}{*}{$\overline{A C T B}$} & \multirow[t]{2}{*}{ NM_001101.3 } & F: TCACCCACACTGTGCCCATCTACGA & 25 & \multirow[t]{2}{*}{295} & \multirow[t]{2}{*}{21,22} \\
\hline & & R: CAGCGGAACCGCTCATTGCCAATGG & 25 & & \\
\hline \multirow[t]{2}{*}{ PPBP } & \multirow[t]{2}{*}{ NM_002704.3 } & F: TTGTAGGCAGCAACTCACCC & 20 & \multirow[t]{2}{*}{135} & \multirow[t]{2}{*}{ [59] } \\
\hline & & R: TGCAAGGCATGAAGTGGTCT & 20 & & \\
\hline \multirow{2}{*}{$\begin{array}{l}\text { DEFA1 } \\
\text { IDEFA3 }\end{array}$} & \multirow[t]{2}{*}{ NM_005217.3 } & F: TCCTTGCTGCCATTCTCCTG & 20 & \multirow[t]{2}{*}{204} & \multirow[t]{2}{*}[60]{} \\
\hline & & R: TGCACGCTGGTATTCTGCAA & 20 & & \\
\hline \multirow[t]{2}{*}{ HBA2 } & \multirow[t]{2}{*}{ NM_000517.4 } & F: TCAAGCTCCTAAGCCACTGC & 20 & \multirow[t]{2}{*}{162} & \multirow[t]{2}{*}{ [61] } \\
\hline & & R: CAGGAGGAACGGCTACCGAG & 20 & & \\
\hline \multirow[t]{2}{*}{$H B B$} & \multirow[t]{2}{*}{ NM_000518.4 } & F: GCAACCTCAAACAGACACCA & 20 & \multirow[t]{2}{*}{182} & \multirow[t]{2}{*}[62]{} \\
\hline & & R: CAGCATCAGGAGTGGACAGA & 20 & & \\
\hline \multirow[t]{2}{*}{$I L-1 \beta$} & \multirow[t]{2}{*}{ NM_000576.2 } & F: CCAGCTACGAATCTCCGACC & 20 & \multirow[t]{2}{*}{180} & \multirow[t]{2}{*}{ [63] } \\
\hline & & R: CTGCCTGCTCTTGGCTAACT & 20 & & \\
\hline \multirow[t]{2}{*}{ CCL3 } & \multirow[t]{2}{*}{ NM_002983.2 } & F: CTGCAACCAGTTCTCTGCATC & 21 & \multirow[t]{2}{*}{145} & \multirow[t]{2}{*}[64]{} \\
\hline & & R: TAGGAAGATGACACCGGGCT & 20 & & \\
\hline \multirow[t]{2}{*}{ CCL4 } & \multirow[t]{2}{*}{ NM_002984.3 } & F: CCGCCTGCTGCTITCTTAC & 20 & \multirow[t]{2}{*}{141} & \multirow[t]{2}{*}[65]{} \\
\hline & & R: CACTGGGATCAGCACAGACT & 20 & & \\
\hline \multirow[t]{2}{*}{ SOD2 } & \multirow[t]{2}{*}{ NM_001024466.1 } & F: TGGAAGCCATCAAACGTGACT & 21 & \multirow[t]{2}{*}{173} & \multirow[t]{2}{*}[66]{} \\
\hline & & R: GCCTGTTGTTCCTTGCAGTG & 20 & & \\
\hline
\end{tabular}

\section{Determination of plasma alpha (a)-defensin 1-3 levels by ELISA}

Plasma $\alpha$-defensin 1-3 concentrations were measured by ELISA (Hycult Biotechnology) according to the manufacturer's instructions and as described in our previous study [13].

\section{Determination of plasma haemoglobin}

Free haemoglobin $(\mathrm{Hb})$ in plasma samples was measured spectrophotometrically (Spectrophotometer, Shimadzu UV1700, Kyoto, Japan) with $\mathrm{Na}_{2} \mathrm{CO}_{3}$ solution $(10 \mathrm{mg} /$ $100 \mathrm{ml}$ ) as a reagent as described in a previous study [24]. Absorbance was measured at 415, 450, and $700 \mathrm{~nm}$. The plasma $\mathrm{Hb}$ level was calculated according to the formula:

$$
\mathrm{Hb}=154.7 \times(\mathrm{A} 415)-130.7 \times(\mathrm{A} 450)-123.9 \times(\mathrm{A} 700)
$$

\section{Statistics}

Clinical data are reported as medians (upper and lower range limits). mRNA expression is represented as fold changes relative to $\beta$-actin $(A C T B)$ mRNA in PBMCs. Plasma levels of PPBP, $\alpha$-defensin $1-3, \mathrm{Hb}, \mathrm{CCL} 3, \mathrm{CCL} 4$, and IL $-1 \beta$ are non-parametric data and are also expressed as medians (upper and lower range limits). The significance of the difference between two groups was determined by the Mann-Whitney U test, and differences among the $\mathrm{N}, \mathrm{H}$, and CHD groups were determined by the Kruskal-Wallis test. mRNA expression and plasma PPBP and $\alpha$-defensin 1-3 levels are represented as whisker plots, with boxes denoting the interquartile range and whiskers the minimum/maximum values. Correlations between CHD development, mRNA expression, plasma protein levels, and characteristics/clinical manifestations were determined by Spearman's rho correlation analysis. The $\alpha$ level was set at $<0.05$ with a $95 \%$ confidence interval. All statistical analyzes were performed using SPSS version 18 software (SPSS, Chicago, IL, USA).

\section{Results}

Characteristics of patients and controls

General descriptions and clinical manifestations of patients and controls are compared in Table 2. The age of patients with CHD was significantly higher than that of controls and the $\mathrm{H}$ group (both $p=0.000$ ), but there was no significant difference in age between the $\mathrm{N}$ and $\mathrm{H}$ groups. Levels of $\mathrm{TC}$ in the $\mathrm{H}$ group were significantly higher than those in $\mathrm{N}(p=0.004)$ and CHD groups $(p=0.008)$. The LDL level in the $\mathrm{H}$ group tended to be higher than in the $\mathrm{N}$ group $(p=0.072)$ and was significantly higher than in the CHD group $(p=0.049)$. All groups showed similar TG levels $(p>0.05)$.

\section{mRNA expression in PBMC extracts}

qRT-PCR findings of relative mRNA expression (mean 2-fold changes) of PPBP, DEFA1/DEFA3, HBB, HBA2, 
Table 2 General description and clinical manifestations of the study population

\begin{tabular}{llllll}
\hline Variable & Age (year) & TC $(\mathrm{mg} / \mathrm{dL})$ & $\mathrm{LDL}(\mathrm{mg} / \mathrm{dL})$ & $\mathrm{TG}(\mathrm{mg} / \mathrm{dL})$ & $\mathrm{HDL}(\mathrm{mg} / \mathrm{dL})$ \\
\hline Normal & $42(23-58)$ & $175(156-199)$ & $99(60-111)$ & $147(70-162)$ & $41(31-56)$ \\
Hyperlipidaemia & $42(26-58)$ & $223(150-304)^{\mathrm{b}}$ & $131(63-190)^{\mathrm{c}}$ & $166(103-1181)^{\mathrm{d}}$ & $46(26-80)$ \\
$\begin{array}{l}\text { Coronary Heart Disease } \\
\text { (CHD) }\end{array}$ & $66(58-78)^{\mathrm{a}}$ & $166(115-259)$ & $89(44-174)$ & $92(72-169)$ & $49(37-75)$
\end{tabular}

All patients and controls were male. $N$ normal controls, $H$ and CHD patients with hyperlipidaemia and coronary heart disease, respectively, $T C$ total cholesterol, $T G$ triglyceride, $H D L$ high-density lipoprotein, $L D L$ low-density lipoprotein

Data are shown as medians (ranges). The differences in each variable between two groups ( $\mathrm{N}$ vs. $\mathrm{H}, \mathrm{H}$ vs. CHD, and N vs. CHD) were determined using the MannWhitney $U$ test. The a level was set at $<0.05$ at a $95 \%$ confidence interval. The significantly different variables between groups are as follows

${ }^{a}$ Age of the patients with CHD was significantly more than $\mathrm{N}$ and $\mathrm{H}$ groups $(p=0.000)$

${ }^{b}$ Levels of TC in H were significantly higher than those in $\mathrm{N}(p=0.004)$ and CHD groups $(p=0.008)$

${ }^{c}$ LDL levels in $\mathrm{H}$ was tended to higher than in $\mathrm{N}$ groups $(p=0.072)$, and significantly higher than in CHD group ( $\left.p=0.049\right)$

d There was significant difference in TG levels; $\mathrm{H}>\mathrm{CHD}(p=0.013) ; \mathrm{N}>\mathrm{CHD}(p=0.025)$

SOD2, CCL3, CCL4, and $I L-1 \beta$ in N, H, and CHD groups are shown in Fig. 2a. Only PPBP, DEFA1/DEFA3, $H B B$, and $H B A 2$ showed significant differences in mRNA expression in both $\mathrm{H}$ and $\mathrm{CHD}$ groups compared with the $\mathrm{N}$ group (Fig. 2a). The correlations between mRNA expression of the eight selected genes are summarized in Table 3.

\section{Plasma levels of PPBP, a-defensin 1-3, CCL3, CCL4, and IL-1 $\beta$}

Plasma levels of proteins encoded by the selected genes were compared among groups using ELISA and Milliplex bead techniques (data not shown). As shown in Fig. 2b, a significant difference was only found between PPBP $(r=0.655, p=0.034)$ and $\alpha$-defensin $1-3(r=0.594$, $p=0.003)$ levels among the three groups, which supports the PPBP and DEFA1/DEFA3 expression results.

Correlations between CHD development, mRNA expression, plasma protein levels, and clinical manifestations

All parameters in the $\mathrm{N}, \mathrm{H}$, and $\mathrm{CHD}$ groups were tested for correlations. Significant correlations between mRNA expression levels are summarized in Table 3, while correlations between characteristics/clinical manifestations and plasma PPBP or $\alpha$-defensin 1-3 levels are shown in Table 4. Both plasma PPBP and $\alpha$-defensin 1-3 levels were significantly positively correlated with age, and TC and LDL levels, but not TG or HDL levels. Additionally, significant genotype and phenotype associations between PPBP and DEFA1/DEFA3 $\left(r_{\mathrm{s}}=0.363, p=0.041\right)$ and plasma PPBP and $\alpha$-defensin $1-3$ levels $\left(r_{\mathrm{s}}=0.458\right.$, $p=0.021$ ) were detected (Fig. 3c).

\section{Discussion}

In this cross-sectional study, $\mathrm{N}, \mathrm{H}$, and $\mathrm{CHD}$ groups were representative of the long-term development of CHD, which is a common complication of atherosclerosis. This study focused on verifying markers for potential CHD prediction in non-familial Thai hyperlipidaemia patients. Our findings revealed that: 1) there was significant association between increased genotypic and phenotypic PPBP and DEFA1/DEFA3 expression in $\mathrm{H}$ and CHD groups; and 2) PPBP and DEFA1/DEFA3

Table 3 Significant correlations between mRNA expression of gene profile

\begin{tabular}{|c|c|c|c|c|c|c|c|c|}
\hline Gene & PPBP & DEFA1/DEFA3 & HBA2 & $H B B$ & $I L-1 \beta$ & $\mathrm{CCL} 3$ & CCL4 & SOD2 \\
\hline PPBP & & $\begin{array}{c}0.3633 \\
(p=0.0410)\end{array}$ & $\begin{array}{l}0.4961 \\
(p=0.0028)\end{array}$ & $\begin{array}{l}0.4261 \\
(p=0.0120)\end{array}$ & & & $\begin{array}{l}0.3533 \\
(p=0.0437)\end{array}$ & $\begin{array}{l}0.3780 \\
(p=0.0301)\end{array}$ \\
\hline $\begin{array}{l}\text { DEFA1/ } \\
\text { DEFA3 }\end{array}$ & $\begin{array}{l}0.3633 \\
(p=0.0410)\end{array}$ & & & & & & & \\
\hline HBA2 & $\begin{array}{l}0.4961 \\
(p=0.0028)\end{array}$ & & & $\begin{array}{l}0.8487 \\
(p<0.0001)\end{array}$ & & $\begin{array}{l}0.4138 \\
(p=0.0167)\end{array}$ & $\begin{array}{l}0.4203 \\
(p=0.0133)\end{array}$ & $\begin{array}{l}0.5560 \\
(p=0.0006)\end{array}$ \\
\hline$H B B$ & $\begin{array}{l}0.4261 \\
(p=0.0120)\end{array}$ & & $\begin{array}{l}0.8487 \\
(p<0.0001)\end{array}$ & & & $\begin{array}{l}0.3626 \\
(p=0.0381)\end{array}$ & $\begin{array}{l}0.3595 \\
(p=0.0368)\end{array}$ & $\begin{array}{l}0.4747 \\
(p=0.0046)\end{array}$ \\
\hline$I L-1 \beta$ & & & & & & $\begin{array}{l}0.6199 \\
(p<0.0001)\end{array}$ & $\begin{array}{l}0.7173 \\
(p<0.0001)\end{array}$ & $\begin{array}{l}0.5514 \\
(p=0.0007)\end{array}$ \\
\hline CCL3 & & & $\begin{array}{l}0.4138 \\
(p=0.0167)\end{array}$ & $\begin{array}{l}0.3626 \\
(p=0.0381)\end{array}$ & $\begin{array}{c}0.6199 \\
(p<0.0001)\end{array}$ & & $\begin{array}{l}0.6269 \\
(p<0.0001)\end{array}$ & $\begin{array}{l}0.5587 \\
(p=0.0006)\end{array}$ \\
\hline CCL4 & $\begin{array}{l}0.3533 \\
(p=0.0437)\end{array}$ & & $\begin{array}{l}0.4203 \\
(p=0.0133)\end{array}$ & $\begin{array}{l}0.3595 \\
(p=0.0368)\end{array}$ & $\begin{array}{c}0.7173 \\
(p<0.0001)\end{array}$ & $\begin{array}{l}0.6269 \\
(p<0.0001)\end{array}$ & & $\begin{array}{l}0.8701 \\
(p<0.0001)\end{array}$ \\
\hline SOD2 & $\begin{array}{l}0.3780 \\
(p=0.0301)\end{array}$ & & $\begin{array}{l}0.5560 \\
(p=0.0006)\end{array}$ & $\begin{array}{l}0.4747 \\
(p=0.0046)\end{array}$ & $\begin{array}{c}0.5514 \\
(p=0.0007)\end{array}$ & $\begin{array}{l}0.5587 \\
(p=0.0006)\end{array}$ & $\begin{array}{l}0.8701 \\
(p<0.0001)\end{array}$ & \\
\hline
\end{tabular}

The mRNA expressions of gene profile were non-parametric data (mean of fold change). Correlations ( $r_{\mathrm{s}}$ ) between the expressions were analyzed by the RhoSpearman correlation analysis. The level was set at $<0.05$ at a $95 \%$ confidence interval. Only significant correlations were shown 
Table 4 Correlations between clinical data and plasma PPBP or a -defensin 1-3

\begin{tabular}{llllll}
\hline Variables & Age & TC & LDL & TG & HDL \\
\hline PPBP & 0.604 & 0.577 & 0.543 & 0.081 & -0.149 \\
& $(\boldsymbol{p}=\mathbf{0 . 0 2 5})^{*}$ & $(\boldsymbol{p}=\mathbf{0 . 0 4 3})^{*}$ & $(\boldsymbol{p}=\mathbf{0 . 0 3 9})^{*}$ & $0.785)$ & $(p=0.596)$ \\
a-de a-defensin & 0.602 & 0.530 & 0.525 & 0.088 & -0.087 \\
& $(\boldsymbol{p}=\mathbf{0 . 0 0 5})^{*}$ & $(\boldsymbol{p}=\mathbf{0 . 0 2 4})^{*}$ & $(\boldsymbol{p}=\mathbf{0 . 0 3 0})^{*}$ & $(p=0.721)$ & $(p=0.714)$ \\
\hline
\end{tabular}

Plasma levels of PPBP, $a$-defensin 1-3, and clinical manifestations were non parametric data Correlations $\left(r_{s}\right)$ between variables were analyzed by the Rho-Spearman correlation analysis. The a level was set at $<0.05$ at a $95 \%$ confidence interval. * refers to a significant correlation $(p<0.05)$

expression was significantly correlation with CHD development. Based on these data, we suggest that significantly increased expression of both PPBP and DEFA1/ $D E F A 3$ and their encoded proteins has the potential to be established as a synergistic predictive biomarker for CHD risk in hyperlipidaemia patients.

Previous histological studies of atherogenesis revealed that early-stage (fatty streak) atherosclerotic lesions to more complicated lesions demonstrate chronic inflammation. This develops from an interaction between plasma lipoproteins, cellular components such as monocytes, macrophages, T lymphocytes, B lymphocytes, endothelial cells (ECs), and smooth muscle cells, and the extracellular matrix of the arterial wall [2]. Polymorphonuclear neutrophils (PMNs) have also been shown to play a prominent innate inflammatory role in atherogenesis in humans [18], mice [25], and pigs [26]. PMNs were observed in plaque ruptures and erosions of human lesions, and in thrombi from acute coronary syndrome patients [27]. Previous studies have hypothesized that the number of PMNs in circulation, and the amount of PMN-produced elastase and myeloperoxidase, correlate with both atherosclerosis [27, 28] and myocardial infarction [29].

During inflammation, large amounts of intracellular proteins are released from activated PMNs into the extracellular milieu as an outcome of PMN degranulation, leakage during phagosome formation, and cell death. The amount of highly homologous human neutrophil peptides (HNPs)-1, -2 , and -3 , or $\alpha$-defensin is more than half of the total protein content within PMN azurophilic granules [30]. $\alpha$-defensin is a cysteine-rich positively-charged polypeptide produced and released from activated PMN granules. The $\alpha$-defensin genes DEFA1/DEFA3 encode HNP-1, 2, and 3 [31, 32]. Previous studies have reported that HNP $1-3$ play a role in EC dysfunction during early atherogenesis. HNP levels are also markedly increased in inflammation, including sepsis and acute coronary vascular disorders [7]. Moreover, we recently showed that $\alpha$-defensin $1-3$ expression levels were associated with CHD development [13].

A role for platelets and platelet-derived factors in atherosclerosis has long been suggested beyond their function in the hemostatic system. Platelets are also involved in thrombus formation in response to vascular injury, and affect coronary, cerebral, and peripheral circulation [33]. Following activation, platelet $\alpha$-granules rapidly release chemokines which play an important role in atherogenesis. Most chemokines attract specific leukocyte subsets to the lesion site, but they also influence the proliferation, differentiation, and degranulation of various cell types. They may exert their effects either alone or synergistically with other chemokines via different G-proteincoupled receptors expressed in target cells, some of which remain to be identified. Certain chemokines also regulate the expression or processing of the precursors of other chemokines [34].

Pro-platelet basic protein (PPBP) or chemokine (C-X$\mathrm{C}$ motif) ligand 7 (CXCL7) is an encoded protein, which is a small cytokine of the CXC chemokine family. PPBP is released in large amounts from activated platelets and is involved in the response to vascular injury [35]. It stimulates various processes including mitogenesis, glucose metabolism, and the synthesis of extracellular matrix and plasminogen activator [36, 37].

In the present study, we found that the mRNA expression of PPBP, DEFA1/DEFA3, HBA2, and $H B B$ was significantly increased in $\mathrm{H}$ and $\mathrm{CHD}$ groups of patients compared with controls, although plasma protein validation only revealed significant increases in PPBP and $\alpha-$ defensin 1-3. This indicates that the transcriptional and post-transcriptional processes of $P P B P$ and DEFA1/ $D E F A 3$ were successful. In agreement with a previous study [7], our observations suggest roles for platelets and neutrophils in CHD development. Because both PPBP [35] and $\alpha$-defensin 1-3 [30] are released in large quantities from their respective cells, it may be feasible for them to be used as biomarkers. Table 4 summarizes the significant correlations of both plasma PPBP and $\alpha$ defensin 1-3 with age, TC, and LDL, but not HDL. In support of this observation, oxidized LDL and the remnant lipoproteins beta-very low density lipoproteins have been reported to play a critical role in the proinflammatory reaction in atherogenesis, whereas HDL, an anti-atherogenic lipoprotein, exerts anti-inflammatory functions [1].

Hypercholesterolaemia is typically an asymptomatic condition that is often detected during routine screening. Our findings suggest the possibility of applying the plasma proteins PPBP and $\alpha$-defensin $1-3$ as $C H D$ risk 

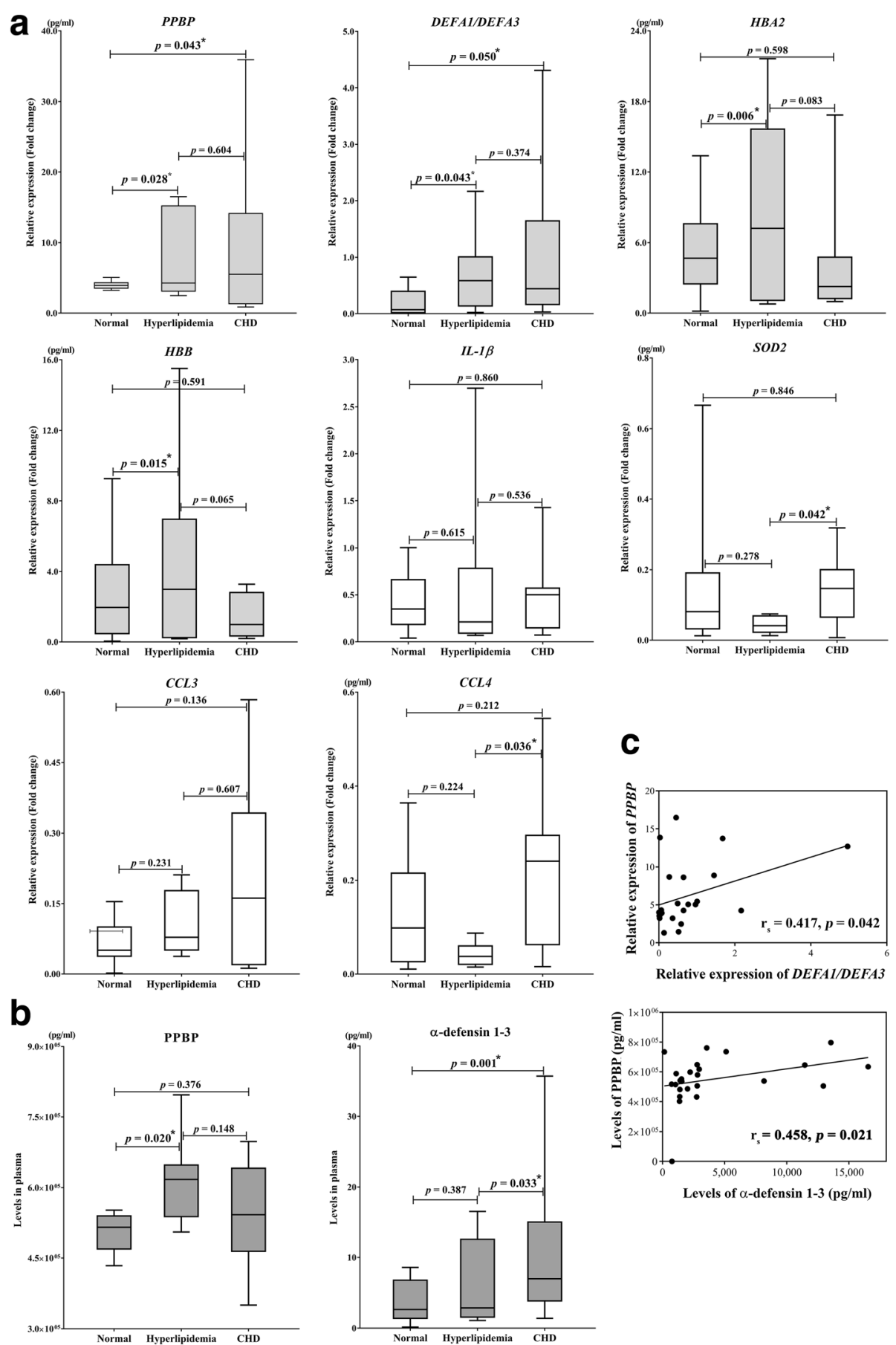

Fig. 3 Expression of eight selected genes showing altered expression in patient groups vs. controls. (a) mRNA expression (2.0-fold change) relative to $\beta$-actin mRNA in PBMCs obtained from controls, and hyperlipidaemia and CHD patients post-bypass surgery, as determined by qRTPCR. Data are presented as the mean 2.0-fold change relative to control \pm SEM $(n=10)$. (b) Plasma levels $(\mathrm{pg} / \mathrm{ml})$ of PPBP and a-defensin $1-3$ from healthy controls $(n=20)$, hyperlipidaemia patients $(n=24)$, and CHD patients post-bypass surgery $(n=21)$. Data are illustrated as whisker plots, with boxes denoting the interquartiles range (IQR) and whiskers the minimum/maximum values. (c) Correlations between relative expression of PPBP and DEFA1/DEFA3, and between plasma levels of PPBP and a-defensin 1-3. "refers to a significant difference $(p>0.05)$

markers in hyperlipidaemia patients. The significant genotype $\left(r_{s}=0.363, p=0.041\right)$ and phenotype correlations $\left(r_{s}=0.458, p=0.021\right)$ between PPBP and DEFA1/
$D E F A 3$ shown in Fig. 3c indicate that these predictive gene markers could be combined synergistically, although further studies in larger sample sizes of 
randomized multi-center populations should be conducted to verify this hypothesis. Previous reports of platelet-neutrophil aggregates include their detection in an acute febrile illness characterized by systemic vasculitis (Kawasaki disease), in which they were closely associated with the pathological development of coronary artery abnormalities [38]. Similarly, a platelet-neutrophil interaction was previously shown to contribute to hepatic ischemia/reperfusion injury in mice [39].

Several studies have demonstrated correlations between $\mathrm{Hb}$ and chronic stress in humans [40], as well as rats [40, 41], mice [35], and pigs [42]. Hb plays an important role in neuronal respiration, oxidative stress, and response to injury. Animals expressing the highest level of mRNA for $\mathrm{Hb}$ also showed increased expression of genes associated with the vascular system and injury response [40, 41, 43, 44]. Most studies have identified correlations between chronic social stress and brain vascular injury related to stroke, while few have investigated the relationship between $\mathrm{Hb}$ and CVD. For example, a recent study indicated that hemoglobin genes $H B B-B 1$, $H B B-B 2, H B A-A 1, H B A-A 2$, and $B E T A-S$ were potential markers of chronic social stress, which induces vascular dysfunction in mice [35]. Prior studies have also demonstrated associations between increasing levels of $\mathrm{HbA1c}$ and risk of death, myocardial infarction, stroke, and coronary revascularization [45-47]. In the present study, we found that increased $H B A 2$ and $H B B$ mRNA expression was not significantly associated with translation into protein. However, we noted that $H B A 2$ and $H B B$ mRNA expression was significantly correlated with that of $P P B P$ $\left(r_{s}=0.4961, p=0.0028 ; r_{s}=0.4261, p=0.012\right.$, respectively). We therefore suggest that $H B A 2$ and $H B B$ should be investigated to determine whether they could be alternative prognostic biomarkers for CHD.

We observed no significant increase in the expression of mRNAs of the other selected genes in $\mathrm{H}$ and $\mathrm{CHD}$ groups (Fig. 3). Additionally, their plasma-encoded

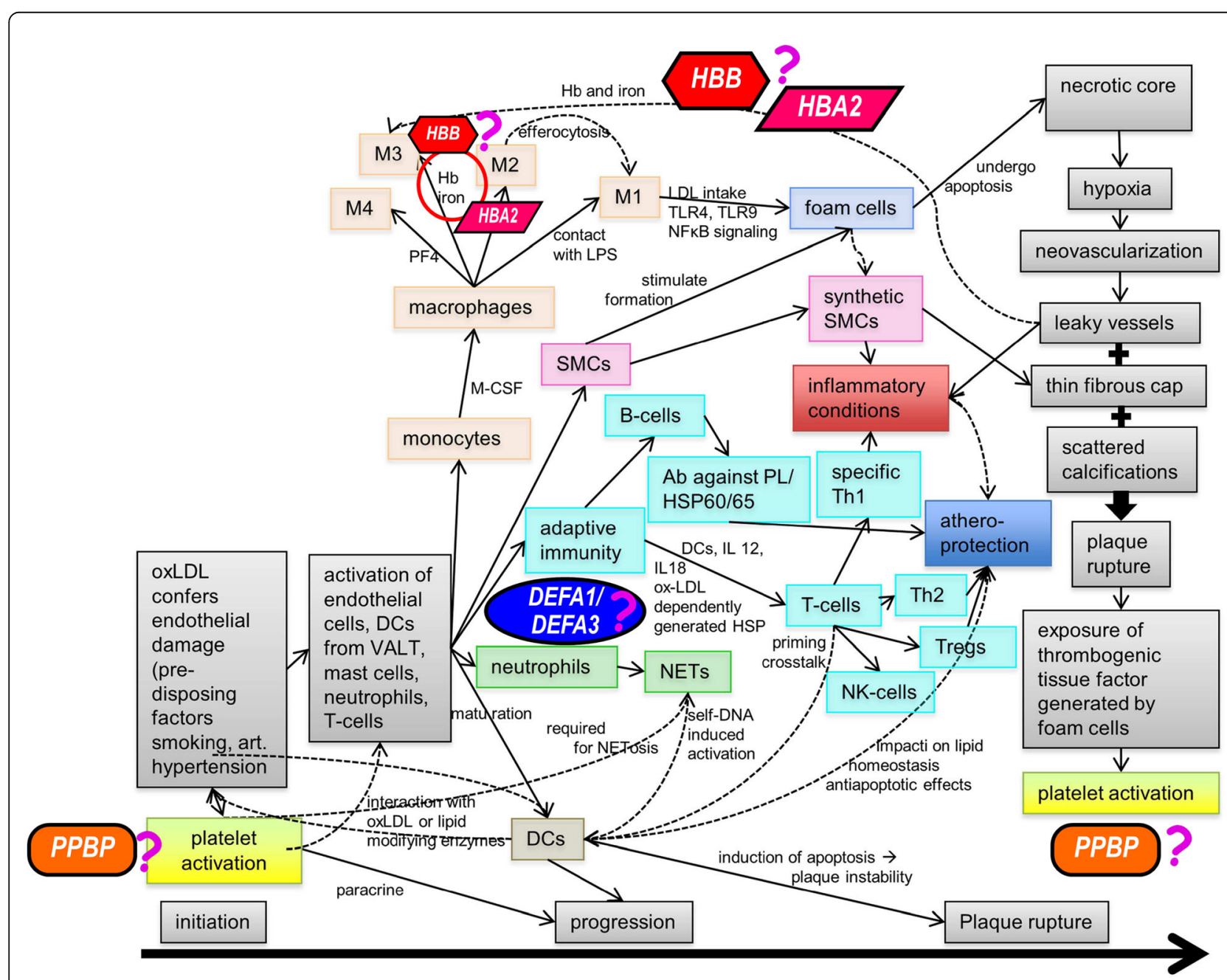

Fig. 4 Possible roles and interplay of our potential predictive inflammatory markers; including PPBP, DEFA1/DEFA3, HBA2, and $H B B$ in the network of atherogenesis and complications of coronary heart disease [55] 
proteins, including IL- $\beta$, SOD2, CCL3, and CCL4, were not significantly altered. It is possible that this represents incomplete transcription or post-transcriptional processes, or that our detection techniques were not appropriate. However, we observed significant correlations among the mRNA expression levels of these genes (Table 3). These findings support the existence of interplays between pro-inflammatory cytokines, cytokines, and chemokines in CHD development. In agreement with this, previous studies suggest that our selected gene profile is involved in the development of atherogenesis and CHD [7, 34, 35, 48-54] (Fig. 2). Moreover, Fig. 4 from a previous study [55] illustrates the possible roles and network interactions of various factors in atherogenesis and CHD development. Based on our results, we suggest that our potential gene markers including $P P B P$, $D E F A 1 / D E F A 3, H B A 2$, and $H B B$ demonstrate interplay within the network. Further investigation and confirmation of mRNA and protein expression may provide more effective predictions of $\mathrm{CHD}$ in hyperlipidemia patients.

Table 2 shows that the ages of the $\mathrm{N}$ and $\mathrm{H}$ groups were not significantly different. The ages of the patients with $\mathrm{CHD}$ were significantly higher than the $\mathrm{N}$ and $\mathrm{H}$ groups $(p=0.000)$. Our result agrees with long-term atherogenesis and the development of CHD complications $[2,7]$. This was the key aim of our cross- sectional study, which was designed to cover a shorter observation time, from the initiation of atherosclerosis to the development of complete CHD [56,57].

The present study had some limitations, including 1) its small sample size and single-center analysis, 2) In determining DEFA1/DEFA3 expression using a qRT-PCR with our designed primers, the amplicon size of the DEFA1/DEFA3 gene (204 bp) was slightly larger than ideal (70-200 bp) for maximum efficiency [58]. Our PCR conditions were confirmed by agarose gel electrophoresis and melting curve analysis. Melting curve analysis of DEFA1/DEFA3 showed a single peak. Similarly, agarose gel electrophoresis of the amplicon was a single band. Therefore, our DEFA1/DEFA3 gene primer was sufficiently specific and suitable for qRT-PCR, 3) the lack of Milliplex kit optimization, which may have accounted for the observed variation in its performance; future work should determine if heparin in plasma interferes with the binding capacity, whether the 1:100 dilution of plasma samples is appropriate, the optimal incubation time, and if artifacts interfere with plasma protein levels, and 4) the lack of plasma SOD2 level determination which reflects the fact that SOD2 enzyme and cytokine/chemokine analysis could not be conducted using the same Milliplex set. An appropriate SOD2 assay should therefore be performed to verify its importance as a CHD biomarker in future studies.

\section{Conclusion}

We conducted a cross-sectional study of the evaluation of CHD predictive biomarkers in non-familial hyperlipidaemia. Among eight potential markers, $P P B B$ and $D E F A 1 / D E F A 3$ were the most strongly correlated with CHD development, and show promise for further application as inflammatory markers to synergistically predict the risk of CHD development in Thai hyperlipidaemia patients.

\section{Abbreviations \\ CHD: Coronary heart disease; ELISA: Enzyme-linked immunosorbent assay; HDL: High-density lipoprotein; HNP 1-3: Human neutrophil peptides 1-3; LDL: Low-density lipoprotein; PBMC: Peripheral blood mononuclear cells; qRT-PCR: Quantitative reverse transcription-polymerase chain reaction; TC: Total cholesterol; TG: Triglyceride; a-defensin: Alpha-defensin}

\section{Acknowledgements}

We thank the volunteers and patients who donated their blood and the staff at Pramongkutklao Hospital for their cooperation in blood collection, taking consent from patients and filling out the questionnaire voluntarily. Thanks also to Edanz Group Ltd. (https://www.edanzediting.com) and Mr. Paul Adams, who provided editorial assistance.

\section{Funding}

This study was supported by the Faculty of Tropical Medicine, Mahidol University; the Mahidol University Research Fund of the National Research Council of Thailand (2011-2012)

\section{Availability of data and materials}

The datasets during and/or analysed during the current study are available from the corresponding author on reasonable request.

\section{Authors' contributions}

KP selected healthy control, hyperlipidemia and CHD patients, and conducted their coronary bypass grafting. YM and WD were responsible for laboratory work including plasma collection and PBMC preparation. YM and WD performed DNA microarray analysis and ELISA assays. SB carried out the qRT-PCR assays and analyses. YM was responsible for data analysis and statistical calculations. YM conceived the study and wrote the manuscript. All authors interpreted the results, and read and approved the final manuscript.

\section{Competing interests}

The authors declare that they have no competing interests.

\section{Publisher's Note}

Springer Nature remains neutral with regard to jurisdictional claims in published maps and institutional affiliations.

\section{Author details \\ 'Department of Tropical Pathology, Faculty of Tropical Medicine, Mahidol University, Bangkok 10400, Thailand. ${ }^{2}$ Pramongkutklao Hospital and College of Medicine, Bangkok 10400, Thailand. ${ }^{3}$ Center of Excellence for Antibody Research, Faculty of Tropical Medicine, Mahidol University, Bangkok 10400, Thailand.}

Received: 7 March 2017 Accepted: 12 April 2017

Published online: 19 April 2017

\section{References}

1. Fan J, Watanabe T. Inflammatory reactions in the pathogenesis of atherosclerosis. J Atheroscler Thromb. 2003;10:63-71.

2. Libby P. Inflammation in atherosclerosis. Arterioscler Thromb Vasc Biol. 2012 32:2045-51

3. Weber $\mathrm{C}$, Noels $\mathrm{H}$. Atherosclerosis: current pathogenesis and therapeutic options. Nat Med. 2011;17:1410-22. 
4. Anand SS, Islam S, Rosengren A, Franzosi MG, Steyn K, Yusufali AH, Keltai M, Diaz R, Rangarajan S, Yusuf S, Investigators I. Risk factors for myocardial infarction in women and men: insights from the INTERHEART study. Eur Heart J. 2008:29:932-40.

5. Scheuner MT. Genetic evaluation for coronary artery disease. Genet Med. 2003:5:269-85

6. Kang JG, Patino WD, Matoba S, Hwang PM. Genomic analysis of circulating cells: a window into atherosclerosis. Trends Cardiovasc Med. 2006;16:163-8.

7. Hansson GK. Inflammation, atherosclerosis, and coronary artery disease. N Engl J Med. 2005;352:1685-95.

8. Zebrack JS, Anderson JL, Maycock CA, Horne BD, Bair TL, Muhlestein JB. Intermountain heart collaborative study G. Usefulness of high-sensitivity C reactive protein in predicting long-term risk of death or acute myocardial infarction in patients with unstable or stable angina pectoris or acute myocardial infarction. Am J Cardiol. 2002:89:145-9.

9. Melander O, Newton-Cheh C, Almgren P, Hedblad B, Berglund G, Engstrom G, Persson M, Smith JG, Magnusson M, Christensson A, et al. Novel and conventional biomarkers for prediction of incident cardiovascular events in the community. JAMA. 2009;302:49-57.

10. Ridker PM, Paynter NP, Rifai N, Gaziano JM, Cook NR. C-reactive protein and parental history improve global cardiovascular risk prediction: the Reynolds Risk Score for men. Circulation. 2008;118:2243-51. 4p following 51

11. Rosenberg S, Elashoff MR, Beineke P, Daniels SE, Wingrove JA, Tingley WG, Sager PT, Sehnert AJ, Yau M, Kraus WE, et al. Multicenter validation of the diagnostic accuracy of a blood-based gene expression test for assessing obstructive coronary artery disease in nondiabetic patients. Ann Intern Med. 2010;153:425-34.

12. Wingrove JA, Daniels SE, Sehnert AJ, Tingley W, Elashoff MR, Rosenberg S, Buellesfeld L, Grube E, Newby LK, Ginsburg GS, Kraus WE. Correlation of peripheral-blood gene expression with the extent of coronary artery stenosis. Circ Cardiovasc Genet. 2008;1:31-8.

13. Maneerat $Y$, Prasongsukarn $K$, Benjathummarak S, Dechkhajorn W, Chaisri U. Increased alpha-defensin expression is associated with risk of coronary heart disease: a feasible predictive inflammatory biomarker of coronary heart disease in hyperlipidemia patients. Lipids Health Dis. 2016;15:117.

14. Moore DF, Li H, Jeffries N, Wright V, Cooper Jr RA, Elkahloun A, Gelderman MP, Zudaire E, Blevins G, Yu H, et al. Using peripheral blood mononuclear cells to determine a gene expression profile of acute ischemic stroke: a pilot investigation. Circulation. 2005;111:212-21.

15. Sharp FR, Xu H, Lit L, Walker W, Pinter J, Apperson M, Verro P. Genomic profiles of stroke in blood. Stroke. 2007;38:691-3.

16. Untergasser A, Cutcutache I, Koressaar T, Ye J, Faircloth BC, Remm M, Rozen SG. Primer3-new capabilities and interfaces. Nucleic Acids Res. 2012;40: e115.

17. Goff Jr DC, Lloyd-Jones DM, Bennett G, Coady S, D'Agostino Sr RB, Gibbons R, Greenland P, Lackland DT, Levy D, O'Donnell CJ, et al. 2013 ACC/AHA guideline on the assessment of cardiovascular risk: a report of the American College of Cardiology/American Heart Association task force on practice quidelines. J Am Coll Cardiol. 2014;63:2935-59.

18. Dorweiler B, Torzewski M, Dahm M, Kirkpatrick CJ, Lackner KJ, Vahl CF. Subendothelial infiltration of neutrophil granulocytes and liberation of matrix-destabilizing enzymes in an experimental model of human neointima. Thromb Haemost. 2008:99:373-81.

19. Hansen KF, Sakamoto K, Pelz C, Impey S, Obrietan K. Profiling status epilepticus-induced changes in hippocampal RNA expression using highthroughput RNA sequencing. Sci Report. 2014;4:6930.

20. Loseke S, Grage-Griebenow E, Wagner A, Gehlhar K, Bufe A. Differential expression of IFN-alpha subtypes in human PBMC: evaluation of novel realtime PCR assays. J Immunol Methods. 2003;276:207-22.

21. Heid CA, Stevens J, Livak KJ, Williams PM. Real time quantitative PCR. Genome Res. 1996;6:986-94.

22. Kotepui M, Thawornkuno C, Chavalitshewinkoon-Petmitr P, Punyarit $P$, Petmitr S. Quantitative real-time RT-PCR of ITGA7, SVEP1, TNS1, LPHN3, SEMA3G, KLB and MMP13 mRNA expression in breast cancer. Asian Pac J Cancer Prev. 2012;13:5879-82.

23. Moncunill G, Aponte JJ, Nhabomba AJ, Dobano C. Performance of multiplex commercial kits to quantify cytokine and chemokine responses in culture supernatants from plasmodium falciparum stimulations. Plos One. 2013;8: e52587

24. Fairbanks VF. Polycythemia Vera: the packed Cell volume and the curious logic of the red cell mass. Hematology. 1999;4:381-95.
25. van Leeuwen M, Gijbels MJ, Duijvestijn A, Smook M, van de Gaar MJ, Heeringa $P$, de Winther MP, Tervaert JW. Accumulation of myeloperoxidasepositive neutrophils in atherosclerotic lesions in LDLR-/- mice. Arterioscler Thromb Vasc Biol. 2008:28:84-9.

26. Kougias P, Chai H, Lin PH, Yao Q, Lumsden AB, Chen C. Neutrophil antimicrobial peptide alpha-defensin causes endothelial dysfunction in porcine coronary arteries. J Vasc Surg. 2006;43:357-63.

27. Naruko T, Ueda M, Haze $K$, van der Wal AC, van der Loos CM, Itoh A, Komatsu R, Ikura Y, Ogami M, Shimada Y, et al. Neutrophil infiltration of culprit lesions in acute coronary syndromes. Circulation. 2002;106: 2894-900.

28. Ovbiagele B, Lynn MJ, Saver JL, Chimowitz MI, Group WS. Leukocyte count and vascular risk in symptomatic intracranial atherosclerosis. Cerebrovasc Dis. 2007;24:283-8.

29. Kawaguchi H, Mori T, Kawano T, Kono S, Sasaki J, Arakawa K. Band neutrophil count and the presence and severity of coronary atherosclerosis. Am Heart J. 1996:132:9-12.

30. Ganz T, Lehrer RI. Defensins. Curr Opin Immunol. 1994;6:584-9.

31. Aldred PM, Hollox EJ, Armour JA. Copy number polymorphism and expression level variation of the human alpha-defensin genes DEFA1 and DEFA3. Hum Mol Genet. 2005:14:2045-52.

32. Linzmeier RM, Ganz T. Human defensin gene copy number polymorphisms: comprehensive analysis of independent variation in alpha- and betadefensin regions at 8p22-p23. Genomics. 2005;86:423-30.

33. Meadows TA, Bhatt DL. Clinical aspects of platelet inhibitors and thrombus formation. Circ Res. 2007;100:1261-75.

34. Gleissner CA, von Hundelshausen P, Ley K. Platelet chemokines in vascular disease. Arterioscler Thromb Vasc Biol. 2008:28:1920-7.

35. Stankiewicz AM, Goscik J, Swiergiel AH, Majewska A, Wieczorek M, Juszczak GR, Lisowski P. Social stress increases expression of hemoglobin genes in mouse prefrontal cortex. BMC Neurosci. 2014;15:130.

36. Hristov M, Zernecke A, Bidzhekov K, Liehn EA, Shagdarsuren E, Ludwig A, Weber C. Importance of CXC chemokine receptor 2 in the homing of human peripheral blood endothelial progenitor cells to sites of arterial injury. Circ Res. 2007;100:590-7

37. Majumdar S, Gonder D, Koutsis B, Poncz M. Characterization of the human beta-thromboglobulin gene. Comparison with the gene for platelet factor 4 J Biol Chem. 1991:266:5785-9.

38. Ueno K, Nomura Y, Morita Y, Eguchi T, Masuda K, Kawano Y. Circulating platelet-neutrophil aggregates play a significant role in Kawasaki disease. Circ J. 2015;79:1349-56.

39. Kim K, Li J, Tseng A, Andrews RK, Cho J. NOX2 is critical for heterotypic neutrophil-platelet interactions during vascular inflammation. Blood. 2015; 126:1952-64.

40. Richter F, Meurers BH, Zhu C, Medvedeva VP, Chesselet MF. Neurons express hemoglobin alpha- and beta-chains in rat and human brains. J Comp Neurol. 2009:515:538-47.

41. He Y, Hua Y, Lee JY, Liu W, Keep RF, Wang MM, Xi G. Brain alpha- and betaglobin expression after intracerebral hemorrhage. Transl Stroke Res. 2010;1: $48-56$.

42. van der Staay FJ, Schuurman T, Hulst M, Smits M, Prickaerts J, Kenis G, Korte SM. Effects of chronic stress: a comparison between tethered and loose sows. Physiol Behav. 2010;100:154-64.

43. Biagioli M, Pinto M, Cesselli D, Zaninello M, Lazarevic D, Roncaglia P, Simone R, Vlachouli C, Plessy C, Bertin N, et al. Unexpected expression of alpha- and beta-globin in mesencephalic dopaminergic neurons and glial cells. Proc Natl Acad Sci U S A. 2009;106:15454-9.

44. Schelshorn DW, Schneider A, Kuschinsky W, Weber D, Kruger C, Dittgen T, Burgers HF, Sabouri F, Gassler N, Bach A, Maurer MH. Expression of hemoglobin in rodent neurons. J Cereb Blood Flow Metab. 2009;29:585-95.

45. Blake GJ, Pradhan AD, Manson JE, Williams GR, Buring J, Ridker PM, Glynn RJ. Hemoglobin A1c level and future cardiovascular events among women. Arch Intern Med. 2004;164:757-61.

46. Currie CJ, Peters JR, Tynan A, Evans M, Heine RJ, Bracco OL, Zagar T, Poole $\mathrm{CD}$. Survival as a function of $\mathrm{HbA}(1 \mathrm{c})$ in people with type 2 diabetes: a retrospective cohort study. Lancet. 2010:375:481-9.

47. Timmer JR, Hoekstra M, Nijsten MW, van der Horst IC, Ottervanger JP, Slingerland RJ, Dambrink JH, Bilo HJ, Zijlstra F, van't Hof AW. Prognostic value of admission glycosylated hemoglobin and glucose in nondiabetic patients with ST-segment-elevation myocardial infarction treated with percutaneous coronary intervention. Circulation. 2011;124:704-11. 
48. de Jager SC, Kraaijeveld AO, Grauss RW, de Jager W, Liem SS, van der Hoeven BL, Prakken BJ, Putter H, van Berkel TJ, Atsma DE, et al. CCL3 (MIP-1 alpha) levels are elevated during acute coronary syndromes and show strong prognostic power for future ischemic events. J Mol Cell Cardiol. 2008;45:446-52.

49. Kirii $H$, Niwa $T$, Yamada $Y$, Wada $H$, Saito $K$, Iwakura $Y$, Asano M, Moriwaki $H$, Seishima M. Lack of interleukin-1beta decreases the severity of atherosclerosis in ApoE-deficient mice. Arterioscler Thromb Vasc Biol. 2003; 23:656-60.

50. Lopez-Bermejo A, Chico-Julia B, Castro A, Recasens M, Esteve E, Biarnes J, Casamitjana R, Ricart W, Fernandez-Real JM. Alpha defensins 1, 2, and 3: potential roles in dyslipidemia and vascular dysfunction in humans. Arterioscler Thromb Vasc Biol. 2007;27:1166-71.

51. Montecucco F, Lenglet S, Braunersreuther V, Pelli G, Pellieux C, Montessuit C, Lerch R, Deruaz M, Proudfoot AE, Mach F. Single administration of the CXC chemokine-binding protein Evasin-3 during ischemia prevents myocardial reperfusion injury in mice. Arterioscler Thromb Vasc Biol. 2010; 30:1371-7.

52. Schiffrin EL. Oxidative stress, nitric oxide synthase, and superoxide dismutase: a matter of imbalance underlies endothelial dysfunction in the human coronary circulation. Hypertension. 2008;51:31-2.

53. Sheikine Y. Hansson GK. Chemokines and atherosclerosis. Ann Med. 2004;36: 98-118.

54. Versteylen MO, Manca M, Joosen IA, Schmidt DE, Das M, Hofstra L, Crijns HJ, Biessen EA, Kietselaer BL. CC chemokine ligands in patients presenting with stable chest pain: association with atherosclerosis and future cardiovascular events. Neth Hear J. 2016;24:722-9.

55. Nording HM, Seizer $P$, Langer HF. Platelets in inflammation and atherogenesis. Front Immunol. 2015;6:98.

56. Ren L, Cai J, Liang J, Li W, Sun Z. Impact of cardiovascular risk factors on carotid Intima-media thickness and degree of severity: a cross-sectional study. Plos One. 2015;10:e0144182.

57. van Breukelen-van der Stoep DF, van Zeben D, Klop B, van de Geijn GJ, Janssen HJ, Hazes MJ, Birnie E, van der Meulen N, De Vries MA, Castro CM. Association of Cardiovascular Risk Factors with carotid Intima media thickness in patients with rheumatoid arthritis with low disease activity compared to controls: a cross-sectional study. Plos One. 2015;10:e0140844.

58. Cheung CY, Chen J, Chang TK. Evaluation of a real-time polymerase chain reaction method for the quantification of CYP1B1 gene expression in MCF-7 human breast carcinoma cells. J Pharmacol Toxicol Methods. 2004;49: 97-104.

59. Yeo L, Adlard N, Biehl M, Juarez M, Smallie T, Snow M, Buckley CD, Raza K, Filer A, Scheel-Toellner D. Expression of chemokines CXCL4 and CXCL7 by synovial macrophages defines an early stage of rheumatoid arthritis. Ann Rheum Dis. 2016;75:763-71.

60. Li YX, Lin CQ, Shi DY, Zeng SY, Li WS. Upregulated expression of human alpha-defensins 1,2 and 3 in hypercholesteremia and its relationship with serum lipid levels. Hum Immunol. 2014;75:1104-9.

61. Pang W, Weng X, Ye X, Long J, Wu S, Sun L, Wei C, Chen M, Tang W, Qiu S, Zhang $C$. Identification of a variation in the IVSII of alpha2 gene and its frequency in the population of Guangxi. Gene. 2016;583:24-8.

62. Vinjamur DS, Alhashem YN, Mohamad SF, Amin P, Williams Jr DC, Lloyd JA. Kruppel-like transcription factor KLF1 is required for optimal gamma- and beta-Globin expression in human fetal erythroblasts. Plos One. 2016;11: e0146802.

63. Rai H, Sinha N, Kumar S, Sharma AK, Agrawal S. Interleukin-1 Gene cluster polymorphisms and their association with coronary artery disease: separate evidences from the largest case-control study amongst north Indians and an updated meta-analysis. Plos One. 2016;11:e0153480.

64. Xu J, Alexander DB, ligo M, Hamano H, Takahashi S, Yokoyama T, Kato M, Usami I, Tokuyama T, Tsutsumi $\mathrm{M}$, et al. Chemokine (C-C motif) ligand 3 detection in the serum of persons exposed to asbestos: a patient-based study. Cancer Sci. 2015;106:825-32.

65. Liu JY, Li F, Wang LP, Chen XF, Wang D, Cao L, Ping Y, Zhao S, Li B, Thorne $\mathrm{SH}$, et al. CTL- vs Treg lymphocyte-attracting chemokines, CCL4 and CCL20, are strong reciprocal predictive markers for survival of patients with oesophageal squamous cell carcinoma. Br J Cancer. 2015;113:747-55.

66. Papa L, Hahn M, Marsh EL, Evans BS, Germain D. SOD2 to SOD1 switch in breast cancer. J Biol Chem. 2014;289:5412-6.

\section{Submit your next manuscript to BioMed Central and we will help you at every step:}

- We accept pre-submission inquiries

- Our selector tool helps you to find the most relevant journal

- We provide round the clock customer support

- Convenient online submission

- Thorough peer review

- Inclusion in PubMed and all major indexing services

- Maximum visibility for your research

Submit your manuscript at www.biomedcentral.com/submit 